\title{
Influence of inosine pranobex on cell viability in normal fibroblasts and liver cancer cells
}

\author{
Sylwia Tobólska ${ }^{1}$, Sylwia Terpiłowska ${ }^{2}$, Jerzy Jaroszewski ${ }^{3}$, Andrzej Krzysztof Siwicki ${ }^{4}$ \\ ${ }^{1}$ Vet-Agro Sp. z o.o., 20-616 Lublin, Poland \\ ${ }^{2}$ Laboratory of Environmental Biology, Institute of Environmental Engineering, \\ The John Paul II Catholic University of Lublin, 20-950 Lublin, Poland \\ ${ }^{3}$ Department of Pharmacology and Toxicology, ${ }^{4}$ Department of Microbiology and Clinical Immunology, \\ Faculty of Veterinary Medicine, University of Warmia and Mazury in Olsztyn, 10-957 Olsztyn, Poland
}

Received: March 29, 2018 Accepted: June 21, 2018

\begin{abstract}
Introduction: Inosine pranobex (Isoprinosine) stimulates cell-mediated immune responses to viral infections in humans and might have also therapeutic use in animals. The aim of this study was to compare three in vitro cytotoxicity assays on mouse embryo fibroblasts and liver cancer cells and determine their ability to detect early cytotoxic effects for inosine pranobex. Material and Methods: BALB/3T3 clone A31 and HepG2 cells were incubated with inosine pranobex at concentrations from 0.1 to $1,000 \mu \mathrm{g} / \mathrm{mL}$. Cell viability was determined with the MTT reduction, the LHD release, and the NRU tests. Results: A decrease in the cell viability was observed after incubating the BALB/3T3 clone A31and HepG2 cells with inosine pranobex. Conclusions: Based on the cytotoxicity endpoints measured in these investigations in BALB/3T3 clone A31 cells, it can be concluded that the cell membrane may be the first part of the cell to be affected by inosine pranobex. The disintegration of lysosomes and mitochondria follows mitochondria damage. In HepG2 cells likewise, the cell membrane may be the first part of the cell to be affected by inosine pranobex. Also in liver cancer cells, the disintegration of mitochondria (assessed with the MTT reduction assay) and next of lysosomes (assessed with the NRU assay) follows mitochondria damage.
\end{abstract}

Keywords: inosine pranobex, cell culture, cytotoxicity.

\section{Introduction}

Inosine pranobex (Isoprinosine, Methisoprinol), a combination of the p-acetamidobenzoate salt of $\mathrm{N}, \mathrm{N}$-dimethylamino-2-propanol and inosine in a $3: 1$ molar ratio, is an immunomodulating antiviral drug in humans. It is approved for the treatment of viral infections like mucocutaneous infections due to herpes simplex, influenza, genital warts, and subacute sclerosing panencephalitis (SSPE) (17). Many studies in vitro and under clinical conditions have substantiated the immune-modulating and anti-viral activities of inosine pranobex (13). The toxicological effects in vitro of this compound have not been deeply studied.

Inosine pranobex potentiates $\mathrm{T}$ lymphocyte and phagocytic cell function. Moreover, it enhances mitogen-dependent and antigen-dependent lymphocyte DNA synthesis. It induces the gene expression of phenotypic markers of differentiation on immature precursor $\mathrm{T}$ cells, boosts helper or suppressor $\mathrm{T}$ cell functions, and increases the production of lymphotoxin (2).
The drug has potential therapeutic use in animals. Immunotherapy may be especially beneficial in animals infected with viral strains resistant to currently known antiviral drugs (15). In respect of regulatory requirements, no clinical testing of candidate products for veterinary medicinal use is obligatory to carry out to support the first administration of a new drug for the target animal species and before carrying out clinical trials in larger populations or applying for authorisation to market a drug (3). A broad spectrum of cytotoxicity assays is currently used in the fields of toxicology and pharmacology. To choose an appropriate assay, different parameters, like test compounds, specificity, sensitivity, and detection mechanism, have to be considered (4). The mechanism of cell cytotoxicity demonstrated by an active substance is for clarification in these circumstances, and for this purpose a cell culture system is required for quantitative assay of malignant transformation by the substance. BALB/3T3 mouse fibroblast cells were used in our study to examine the cytotoxic effect of inosine pranobex, since the 
BALB/3T3 system was shown to be sensitive to a wide diversity of potential carcinogens or procarcinogens (14). Human hepatoma HepG2 cells display many characteristics of normal liver cells and they are used as an alternative to animal models and isolated hepatocytes (24). This attribute commended them to this study.

One of the most useful cytotoxicity assays is the thiazolyl blue tetrazolium bromide (MTT) reduction assay, which is a quantitative colorimetric assay. In this test, the yellow tetrazolium salt MTT is reduced in mitochondrial processes of the respiratory chain and in microsomal and cytosolic fractions by living cells to blue formazan crystals (19). The tetrazolium salt is reduced to formazan (9). The MTT assay is a sensitive test which shows linearity over a broad range of cell densities (7).

Another commonly used cytotoxicity test is the lactate dehydrogenase (LDH) assay. This colorimetric assay is based on the detection of lactate dehydrogenase activity which is released from the damaged/lysed cells. The evaluation of cytotoxicity in this assay is based on plasma membrane integrity (12). The increase in LDH concentration in culture supernatant is proportional to the number of lysed/damaged cells. Plasma membrane damage releases LDH into the cell culture media. Extracellular LDH in the cell culture media can be quantified by the two-step enzymatic reaction in which LDH catalyses the conversion of lactate to pyruvate via $\mathrm{NAD}^{+}$reduction to NADH. Next, diaphorase uses $\mathrm{NADH}$ to reduce a tetrazolium salt to a red formazan product. This product can be detected spectrophotometrically. The level of formazan formation is directly proportional to the amount of LDH released into the cell culture medium, which is indicative of cytotoxicity.

The neutral red uptake (NRU) assay is a well-known method for quantifying cytotoxicity of chemicals in cell cultures. The assay is based on the uptake of neutral red dye which accumulates in the lysosomes of uninjured cells. The neutral red uptake in vitro test is often used to estimate starting doses for in vivo acute oral systemic toxicity tests. In the $3 \mathrm{~T} 3$ neutral red uptake (3T3 NRU), the cytotoxicity assay is also used for the identification of safe substances not requiring classification for acute oral toxicity (LD50 $>2000 \mathrm{mg} / \mathrm{kg} \mathrm{b.w.)} \mathrm{according} \mathrm{to} \mathrm{the} \mathrm{EU}$ classification, labelling, and packaging of substances and mixtures (CLP) system (21).

The LDH leakage, NRU, and MTT reduction assays are the most commonly used for the detection of cytotoxicity/cell viability following exposure to various chemicals (8). These methods evaluate new toxicity endpoints, enable the determination of toxicity mechanisms, and as a very important boon currently, play a part in the replacement, reduction, and refinement of the use of animals in toxicity testing. These assays are used to examine the biological mechanisms at the cellular level of new tested substances. This is very important when assessing the safety of substances before launching new products on the market and generates ecotoxicological information and dose-response relationship data for the surveillance of health and the environment. Depending on the risk parameters regulatory agencies may implement appropriate prevention and risk management practices to protect public health and the environment (20).

The aim of this study was to compare three in vitro cytotoxicity assays on mouse embryo fibroblasts and liver cancer cells and determine their ability to detect early cytotoxic effects for inosine pranobex.

\section{Material and Methods}

Chemicals. Dulbecco's Modified Eagle's Medium (DMEM), Eagle's Minimum Essential Medium (EMEM), heat-inactivated Calf Bovine Serum (CBS), and Foetal Bovine Serum (FBS) were purchased from the American Type Culture Collection (ATCC, USA), and Antibiotic Antimycotic solution $(10,000 \mathrm{U} / \mathrm{mL}$ of penicillin, $10 \mathrm{mg} / \mathrm{mL}$ of streptomycin, $25 \mu \mathrm{g} / \mathrm{mL}$ of amphotericin B), an In Vitro Toxicology Assay kit, MTT-based (TOX-1), an In Vitro Toxicology Assay Kit, Neutral Red-based (TOX-4), and an In Vitro Toxicology Assay Kit, Lactic Dehydrogenase-based (TOX-7) were obtained from Sigma-Aldrich (USA). Inosine pranobex (MTP 3110261) was procured from ABC Farmaceutici S.p.A (Italy).

Cell culture and treatment. Mouse embryo fibroblast BALB/3T3 clone A31 cells (ATCC CCL-163) and liver cancer HepG2 cells (ATCC HB-8065) were obtained from the ATCC. The cells were cultured as adherent monolayers in plastic tissue culture dishes in DMEM and EMEM, respectively, and supplemented with Antibiotic Antimycotic solution (1 mL per $100 \mathrm{~mL}$ of cell culture medium) and $10 \%(\mathrm{v} / \mathrm{v})$ heat-inactivated CBS and FBS, respectively). The cells were maintained at $37^{\circ} \mathrm{C}$ in a humidified incubator, with $5 \% \mathrm{CO}_{2}$ in the atmosphere (25).

Inosine pranobex was dissolved in deionised water at the concentration of $10 \mathrm{mg} / \mathrm{mL}$. The final concentration was obtained by dilution in the culture medium, supplemented with serum and antibiotics (25).

Cytotoxicity assays. In order to perform the MTT, LDH, and NRU assays, the cells were cultured on 96-well plates $\left(2 \times 10^{5}\right.$ cells $\left./ \mathrm{mL}\right)$ in $100 \mu \mathrm{L}$ of DMEM, supplemented with serum and Antibiotic Antimycotic solution (1 mL per $100 \mathrm{~mL}$ of cell culture medium). After $24 \mathrm{~h}$, the medium was exchanged for fresh medium supplemented with inosine pranobex at final concentrations of $0.1,0.5,1.0,5,10,50,100,500$, and $1,000 \mu \mathrm{g} / \mathrm{mL}$ in a volume of $100 \mu \mathrm{L}$. These concentrations were the final concentrations in the incubations. After $24 \mathrm{~h}$ of incubation, the MTT reduction, LDH release, and NRU assays were performed according to the manufacturer's instructions.

The MTT reduction assay. The MTT colorimetric assay was performed with the use of TOX-1 according to the manufacturer's instruction. The cells were removed from the incubator, $10 \mu \mathrm{L}$ of MTT was added to each well, and the cells were placed in the incubator 
for $3 \mathrm{~h}$. At the end of the incubation, $100 \mu \mathrm{L}$ of MTT solubilisation solution was added to each well. The plate was incubated at room temperature for $2 \mathrm{~h}$ in the dark. Following this, the absorbance was measured with the use of a Sunrise microplate reader (Tecan, Austria) at $570 \mathrm{~nm}$ wavelength. The cell viability was calculated compared to the control cells on the basis of spectrophotometric measurements and the $\mathrm{IC}_{50}(50 \%$ inhibitory concentration) value was also calculated. The experiment was performed independently six times.

LDH release assay. The $\mathrm{LDH}$ release assay was performed with the use of TOX-7 according to the manufacturer's instruction. Two analyses were prepared in parallel.

Analysis I provided a measure of total LDH (T LDH). The cells were removed from the incubator, $1 / 10 \mathrm{LDH}$ assay lysis solution per well was added, and the cells were incubated for $45 \mathrm{~min}$. Next, the cells were centrifuged at $250 \times \mathrm{g}$ for $4 \mathrm{~min}$ to pellet debris. The aliquot was transferred to a flat-bottom plate to proceed to the enzymatic analysis.

Analysis II provided a measure of LDH release (R LDH) into medium. As in analysis I, the cells were removed from the incubator and centrifuged at $250 \times \mathrm{g}$ for $4 \mathrm{~min}$ to pellet debris. This aliquot was also transferred to a flat-bottom plate to proceed to the enzymatic analysis.

Enzymatic analysis. The LDH assay mixture was prepared by mixing LDH assay cofactor, LDH substrate, and dye solution. This mixture was added to each sample in an amount equal to double the volume of the medium removed for testing. The plate was covered with an opaque material to protect it from light and was incubated for 20-30 min. Subsequently the reaction was terminated by addition of $1 / 10$ volume of $1 \mathrm{~N} \mathrm{HCl}$ to each well. The absorbance was measured with the use of the Sunrise microplate reader at $490 \mathrm{~nm}$ wavelength. The percentage of released LDH was calculated according to the formula: \% of released $\mathrm{LDH}$ (absorbance of $\mathrm{R}$ $\mathrm{LDH} /$ absorbance of $\mathrm{T} \mathrm{LDH}) \times 100 \%$. A curve was drawn on the basis of the results and the $\mathrm{IC}_{50}$ value was calculated. The experiment was performed independently six times.

Neutral Red Uptake assay. The NRU assay was performed using TOX-4 according to the manufacturer's instructions. The cells were removed from the incubator and $0.33 \%$ neutral red solution was added in an amount equal to $10 \%$ of the culture medium volume. The cells were then incubated for $3 \mathrm{~h}$. At the end of the incubation period, the medium was carefully removed and the cells were quickly rinsed with neutral red fixative. The fixative solution was removed and an incorporated dye was then solubilised in a volume of neutral red assay solubilisation solution equal to the original volume of culture medium. The cells were incubated for $10 \mathrm{~min}$ at room temperature. The absorbance was measured with the use of the Sunrise microplate reader at $540 \mathrm{~nm}$ wavelength. The cell viability was calculated compared to the control cells on the basis of spectrophotometric measurements, and the $\mathrm{IC}_{50}$ value was also calculated.
The experiment was performed independently six times like its counterparts.

Statistical analysis of the data. The results were expressed as mean \pm SD and the data were analysed with Student's $t$-test using the Statistica programme (Tibco, USA). In all cases, $\mathrm{P}<0.05$ was considered significant.

\section{Results}

The effects on cell viability in BALB/3T3 clone A31 and HepG2 cells after incubation with inosine pranobex at various concentrations are displayed in Figs 1-3. It can be seen from Fig. 1 that there was a concentration-dependent statistically significant decrease in cell viability in both cell lines assessed by the MTT reduction assay. At a concentration of $0.1 \mu \mathrm{g} / \mathrm{mL}$, the inosine pranobex slightly stimulated the cell viability. Inosine pranobex was toxic above the concentrations of 100,500 , and $1,000 \mu \mathrm{g} / \mathrm{mL}$, reducing cell viability to $79 \%, 47 \%$, and $18 \%$ respectively, in BALB/3T3 clone A31 cells. In HepG2 cells the compound was toxic above the concentrations of 50 , 100,500 , and $1,000 \mu \mathrm{g} / \mathrm{mL}$, reducing cell viability to $55 \%, 44 \%, 36 \%$, and $10 \%$, respectively. The $\mathrm{IC}_{50}$ for inosine pranobex was $500 \mu \mathrm{g} / \mathrm{mL}$ for BALB/3T3 clone A31 cells and $50 \mu \mathrm{g} / \mathrm{mL}$ for HepG2 cells (Table 1).

Cell viability was also determined by the $\mathrm{LDH}$ release assay (Fig. 2). The BALB/3T3 clone A31 cells exposed to inosine pranobex demonstrated a concentrationdependent statistically significant increase in LDH release. Inosine pranobex was toxic above the concentrations of 100,500 , and $1,000 \mu \mathrm{g} / \mathrm{mL}$.

Table 1. Cytotoxicity of inosine pranobex. Inhibitory concentration $\left(\mathrm{IC}_{50}, \mu \mathrm{g} / \mathrm{mL}\right)$

\begin{tabular}{lll}
\hline & BALB/3T3 clone A31 line & HepG2 line \\
\hline MTT reduction assay & 500 & 50 \\
\hline LDH release assay & 100 & 10 \\
\hline NRU assay & 500 & 100 \\
\hline
\end{tabular}

Cytotoxicity to the respective cells (BALB/3T3 clone A31 or HepG2) cultivated with different concentrations of inosine pranobex (range of $0.1-1,000 \mu \mathrm{g} / \mathrm{mL}$ ) was quantified using MTT, LDH, and NRU assays. The table shows the concentration-dependent intoxication of inosine pranobex calculated as $50 \%$ inhibitory concentration $\left(\mathrm{IC}_{50}\right)$

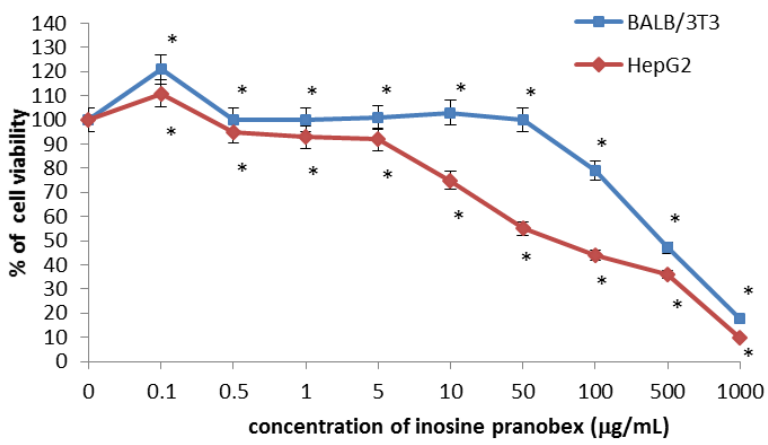

Fig. 1. Cytotoxicity of inosine pranobex in BALB/3T3 clone A31 and HepG2 lines detected with the MTT assay, $\mathrm{n}=6$. Values are given as percentage of cell viability relative to control cells. $* \mathrm{P}<0.05$, compared with control cells 


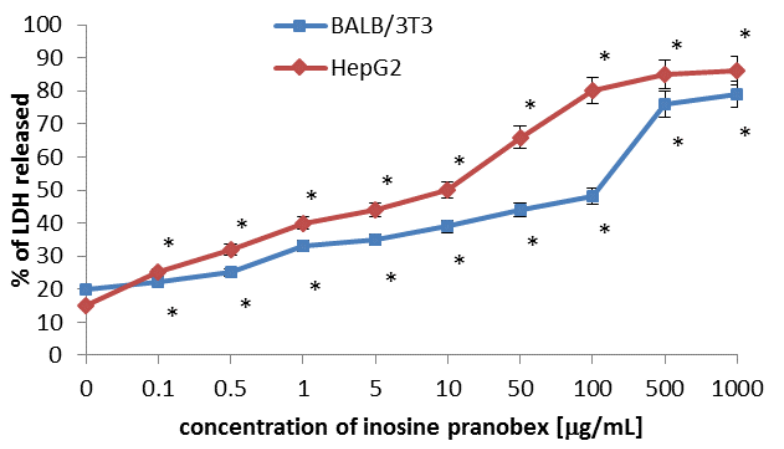

Fig. 2. Cytotoxicity of inosine pranobex in BALB/3T3 clone $A 31$ and HepG2 lines detected with the $\mathrm{LDH}$ assay, $\mathrm{n}=6$. Values are given as percentage of $\mathrm{LDH}$ released. $* \mathrm{P}<0.05$, compared with control cells

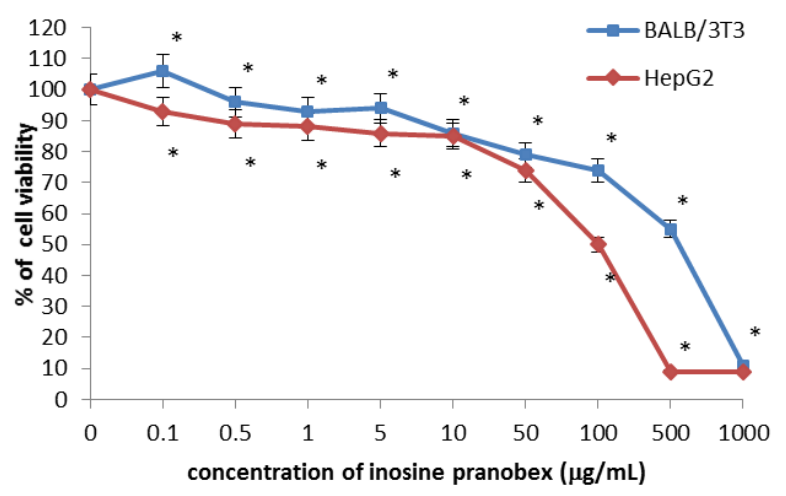

Fig. 3. Cytotoxicity of inosine pranobex in BALB/3T3 clone A31 and HepG2 lines detected with the NRU assay, $n=6$. Values are given as percentage of cell viability relative to control cells. $* \mathrm{P}<0.05$, compared with control cells

An increase by $50 \%$ in the amount of lactate dehydrogenase released into the culture medium was observed in cells incubated at a concentration of $100 \mu \mathrm{g} / \mathrm{mL}$ of inosine pranobex. The HepG2 cells exposed to inosine pranobex demonstrated a concentrationdependent increase of LDH release from the cells. Inosine pranobex was toxic above the concentrations of $10,50,100,500$, and $1,000 \mu \mathrm{g} / \mathrm{mL}$. An increase by $50 \%$ in the amount of lactate dehydrogenase released into the culture medium was observed in cells incubated at a concentration of $10 \mu \mathrm{g} / \mathrm{mL}$ of inosine pranobex (Table 1).

Cell viability was also determined by the NRU assay. It can be seen from Fig. 3 that there was a statistically significant concentration-dependent decrease in cell viability in both cell lines. At a concentration of $0.1 \mu \mathrm{g} / \mathrm{mL}$, inosine pranobex slightly stimulated the cell viability in BALB/3T3 clone A31. A decrease in the cell viability by $50 \%$ was observed in cells incubated with inosine pranobex at a concentration of $500 \mu \mathrm{g} / \mathrm{mL}$ for BALB/3T3 clone A31 and $100 \mu \mathrm{g} / \mathrm{mL}$ for HepG2 cells (Table 1).

\section{Discussion}

The most popular applications of cytotoxicity testing are techniques based on cell viability, measuring staining with MTT or NRU. These methods are usually performed alone or in combination. Results of NRU and MTT assays are comparable $(11,28)$. Borenfreund et al. (5), Triglia et al. (27), and Vian et al. (29) reported close correlations between the NRU and MTT assays for many tested substances. However, some studies showed that different sensitivities between the NRU and MTT assays are obtained for specific test substances such as chloroquine sulphate and anti-neoplastic chemicals (5), non-steroidal anti-inflammatory drugs (1), the carboxylic ionophore monensin $(26,27)$, or polyols. As the cytotoxicity of chemical substances can be mediated by different toxicity mechanisms that influence different endpoints, many recommendations are found in the literature data for the use of varied, mechanistically different endpoint parameters for the evaluation of cytotoxicity. For this purpose, the LDH assay is very useful for examining the three different endpoints on the same cells at the same time (6).

Inosine pranobex is a synthetic drug, consisting of inosine and p-acetamidobenzoate salt of N,Ndimethylamino-2-propanol. It is an immune-modulating agent, which has been reported to potentiate T-lymphocyte and phagocytic cell functions (30). This active substance induces the gene expression of phenotypic markers of differentiation on immature precursor $\mathrm{T}$ cells, boosts helper or suppressor $\mathrm{T}$-cell functions, and increases the production of TNF- $\beta$ (18). The likely mechanism of inosine pranobex-mediated immune modulation should be investigated in vitro under different conditions in various cell lines (23). The safety profile of inosine pranobex has been studied in clinical trials in humans for several indications and populations $(13,16)$. It was shown that this substance has low toxicity, and that doses of the active substance 10 times higher than the therapeutically established dose had no cytotoxic and immunosuppressive action. It has been proved that inosine pranobex has a relatively low degree of both acute and chronic toxicity in both rodent and non-rodent species (10).

The cytotoxic effect of inosine pranobex was assessed using A549 cell line exposed to different concentration ranges from 50 to $800 \mu \mathrm{g} / \mathrm{mL}$ for $48 \mathrm{~h}$. The cytotoxic effect of inosine pranobex was assessed visually using light inverted microscopy and by the MTT colorimetric assay. There were no morphological changes, as assessed visually, in cell cultures treated with inosine pranobex. The MTT cytotoxicity assay confirmed these visual observations under microscope. In the presence of the tested compounds the viability of cells was an average $98.36 \%$ (16).

Based on the cytotoxicity endpoints measured with the above assays, it can be concluded that in mouse embryo fibroblasts the cell membrane may be the first part of the cell to be affected by inosine pranobex (a decrease in cell viability by $50 \%$ was observed in cells incubated at a concentration of $100 \mu \mathrm{g} / \mathrm{mL}$ of inosine pranobex). The disintegration of lysosomes (assessed with the NRU assay) and mitochondria (assessed with the MTT reduction assay) follows cell membrane damage. The $\mathrm{IC}_{50}$ value in the NRU test was $500 \mu \mathrm{g} / \mathrm{mL}$. 
The decrease in the cell viability observed in the MTT reduction test by $50 \%$ was observed in cells incubated with inosine pranobex at a concentration of $500 \mu \mathrm{g} / \mathrm{mL}$. As in fibroblasts, in HepG2 cells also cell membranes may be the first part of the cell to be affected by inosine pranobex (a decrease in cell viability by $50 \%$ was also observed in these cells incubated at a concentration of $10 \mu \mathrm{g} / \mathrm{mL}$ of inosine pranobex). The disintegration of mitochondria (assessed with the MTT reduction assay) and then lysosomes (assessed with the NRU assay) follows mitochondria damage. The $\mathrm{IC}_{50}$ value in MTT reduction test was $50 \mu \mathrm{g} / \mathrm{mL}$. A decrease by $50 \%$ in the cell viability observed in the NRU test was observed in cells incubated with inosine pranobex at a concentration of $100 \mu \mathrm{g} / \mathrm{mL}$. In both cell lines the cell membrane was the first part of the cell to be affected by inosine pranobex. However, in cancer cells, mitochondria are more sensitive when compared to normal cells.

Our study demonstrated that inosine pranobex shows no cytotoxic activity in the BALB/3T3 clone A31 cells up to a concentration of $500 \mu \mathrm{g} / \mathrm{mL}$. The results obtained from both cell lines show that HepG2 cells are the more sensitive when compared to the BALB/3T3 clone A31 cells. Moreover, $\mathrm{LDH}$ release assay is the most sensitive when compared with MTT reduction and NRU assay. In the available literature there are no results of investigations of the impact of inosine pranobex on cell viability. In vitro exposure of cells to inosine pranobex induces a T-lymphocyte differentiation. The drug has been shown to modulate T-lymphocyte and natural killer cell cytotoxicity.

Conflict of Interests Statement: The authors declare that there is no conflict of interests regarding the publication of this article.

Financial Disclosure Statement: This study was supported by the National Centre for Research and Developments (Grant No. UDA-POIG.01.03.01-28108/12).

Animal Rights Statement: None required.

\section{References}

1. Allen C.N., Harpur E.S., Gray T.J.B., Hirst B.H.: Toxic effects of non-steroidal anti-inflammatory drugs in a human intestinal epithelial cell line (HCT-8) as assessed by the MTT and neutral red assays. Toxicol In Vitro 1991, 5, 183-191.

2. Ballet J.J., Morin A., Schmitt C., Agrapart M.: Effect of isoprinosine on in vitro proliferative responses of human lymphocytes stimulated by antigen. Int J Immunopharmacol 1982, 4, 151-157.

3. Beken S., Kasper P., van der Laan J.W.: Regulatory acceptance of alternative methods in the development and approval of pharmaceuticals. Adv Exp Med Biol. 2016, 856, 33-64.

4. Bopp S.K., Lettieri T.: Comparison of four different colourimetric and fluorometric cytotoxicity assays in a zebra fish liver cell line. BMC Pharmacol 2008, 8:8.

5. Borenfreund E., Babich H., Martin-Alguacil N.: Comparisons of two in vitro cytotoxicity assays-the neutral red (NR) and tetrazolium MTT tests. Toxicol In Vitro 1988, 2, 1-6.
6. Chiba K., Kawakami K., Tohyama K.: Simultaneous evaluation of cell viability by neutral red, MTT and crystal violet staining assays of the same cells. Toxicol In Vitro 1998, 12, 251-258.

7. Edmondson J.M., Armstrong L.S., Martinez A.O.: A rapid and simple MTT-based spectro-photometric assay for determining drug sensitivity in monolayer cultures. J Tissue Cult Methods 1988, 11, 15-17.

8. Fotakis G., Timbrell J.A.: In vitro cytotoxicity assays: Comparison of LDH, neutral red, MTT and protein assay in hepatoma cell lines following exposure to cadmium chloride. Toxicol Lett 2006, 5, 160, 171-177.

9. Gonzalez R.J., Tarloff J.B.: Evaluation of hepatic sub-cellular fractions for Alamar Blue and MTT reductase activity. Toxicol In Vitro 2001, 15, 257-259.

10. Hennessy K.J., Blecha F., Pollmann D.S., Kluber E.F.: Isoprinosine and levamisole immunomodulation in artificially reared neonatal pigs. Am J Vet Res 1987, 48, 477-480.

11. Korting H.C., Schindler S., Hartinger A., Kerscher M., Angerpointner T., Maibach H.I.: MTT-assay and neutral red release (NRR)-assay: relative role in the prediction of the irritancy potential of surfactants. Proc Natl Sci Counc Repub China B 1994, $55,533-540$

12. Korzeniewski C., Callewaert D.M.: An enzyme-release assay for natural cytotoxicity. J Immunol Methods 1983, 64, 313-320.

13. Lasek W., Janyst M., Wolny R., Zapała Ł., Bocian K., Drela N.: Immuno-modulatory effects of inosine pranobex on cytokine production by human lymphocytes. Acta Pharm Jun 2015, 65, 171-180.

14. Lubet R.A., Kouri R.E., Curren R.A., Putman D.L., Schechtman L.M.: Induction of mutagenesis and transformation in BALB/c3T3 clone A31-1 cells by diverse chemical carcinogens. Environ Mol Mutagen 1990, 16, 13-20.

15. Majewska A., Lasek W., Janyst M., Młynarczyk G.: In vitro inhibition of HHV-1 replication by inosine pranobex and interferon- $\alpha$. Acta Poloniae Pharmaceutica - Drug Res 2016, 73, 637-644.

16. Majewska A., Lasek W., Młynarczyk G.: Inosine pranobex cytotoxic activities and effect of on replication of human parainfluenza viruses (HPIV-2, HPIV-4), entroviruses (CA16, EV71) and adenoviruses (HAdV-2, HAdV-5) in vitro. Med Dosw Mikrobiol 2015, 67, 107-113.

17. Medicines \& Healthcare products Regulatory Agency (MHRA), 2016. Patient leaflet: information for the user imunovir ${ }^{\circledR} 500 \mathrm{mg}$ tablets.

18. http://www.mhra.gov.uk/home/groups/spcpil/documents/spcpil/c on1476421779978.pdf.

19. Morin A., Ballet J.J.: A recent review on in vitro and in vivo immunological activities of methisoprinol. Allergol Immunopathol 1982, 10, 109-114.

20. Mosmann T.: Rapid colourimetric assay for cellular growth and survival: application to proliferation and cytotoxicity assays. J Immunol Methods 1983, 65, 55-63.

21. NIEHS (National Institute of Environmental Health Sciences), Validation and Regulatory Acceptance of Toxicological Test Methods: A Report of the ad hoc Interagency Co-ordinating Committee on the Validation of Alternative Methods. NIH Publication No. 97-3981. https://ntp.niehs.nih.gov/iccvam/docs/ about_docs/validate.pdf.

22. OECD, 2010. "Guidance Document on Using Cytotoxicity Tests to Estimate Starting Doses for Acute Oral Systemic Toxicity Tests" OECD Guideline for the Testing of Chemicals, Guideline 129, 20 July 2010.

23. Olivier P., Testard P., Marzin D., Abbott D.: Effect of high polyol concentrations on the neutral red absorption assay and tetrazolium-MTT test of rat hepatocytes in primary culture. Toxicol In Vitro 1995, 9, 133-138.

24. Petrova M., Jelev D., Ivanova A., Krastev Z.: Isoprinosine affects serum cytokine levels in healthy adults. J Interferon Cytokine Res 2010, 30, 223-228

25. Scheers E.M., Ekwall B., Dierickx P.J.,: In vitro long-term cytotoxicity testing of 27 MEIC chemicals on HepG2 cells and 
comparison with acute human toxicity data. Toxicol In Vitro 15 2001, 153-161.

26. Terpiłowska S., Siwicki A.K.: Interactions between chromium(III) and iron(III), molybdenum(III) or nickel(II): Cytotoxicity, genotoxicity and mutagenicity studies. Chemosphere 2018, doi: 10.1016/j.chemosphere.2018.03.062.

27. Triglia D., Braa S.S., Donnelly T., Kidd I.: A 3-dimensional human dermal model substrate for in vitro toxicological studies. In: Alternative Methods in Toxicology. Edited by A.M. Goldberg, M.L. Principe. Mary Ann Liebert, New York, 1991, vol. 8, pp. 351-362.

28. Triglia D., Sherard Braa S., Yonan C., Naughton G.K.: Cytotoxicity testing using neutral red and MTT assays on a three- dimensional human skin substrate. Toxicol In Vitro 1991, 5 , 573-578.

29. van de Sandt J.J.M., Rutten A.A.J.J.L., Koeeter H.B.W.M. Cutaneous toxicity testing in organ culture: neutral red uptake and reduction of tetrazolium salt (MTT). Toxicol In Vitro 1993, 7, 81-86.

30. Vian L., Vincent J., Maurin J., Fabre I., Giroux J., Cano J.P.: Comparison of three in vitro cytotoxicity assays for estimating surfactant ocular irritation. Toxicol In Vitro 1995, 9, 185-190.

31. Wybran J., Faman J.P., Gortz R.: Inosiplex (Isoprinosine): a review of its immunological and clinical effects in disease. Adv Pharmacol Ther 1982, 6, 123-131. 